\title{
Role of Bio Pesticides towards Efficient Management of Rhizome Rot in Ginger
}

\author{
S. Behera ${ }^{1 *}$, P. Sial ${ }^{2}$, G. Biswal ${ }^{3}$ and K. S. Pradhan ${ }^{4}$ \\ ${ }^{1}$ Plant Pathology, ${ }^{2}$ Plant breeding and genetics, High Altitude Research Station (O.U.A.T), \\ Pottangi, Koraput, Odisha, India \\ ${ }^{3}$ Department of Plant Pathology, College of Agriculture, O.U.A.T., Bhubaneswar, \\ Odisha, India \\ ${ }^{4}$ Regional Research and Technology Transfer Station, Odisha University of Agriculture \& \\ Technology, Semiliguda, Koraput, Odisha, India \\ *Corresponding author
}

\section{A B S T R A C T}

\begin{tabular}{|l|}
\hline Keyw or d s \\
Bio Pesticides, \\
Rhizome Rot, \\
Ginger
\end{tabular}

Use of Trichoderma harzianum @10 g/lit.+Pseudomonas fluorescens @10 g/lit $+10 \mathrm{~kg} / \mathrm{ha}$ at basal,45 and 90 DAS gave maximum yield (17.62t ha-1) and minimum per cent disease incidence $(4.89 \%)$ next best treatment was seed treatment with Trichoderma viride @10 g/lit. and Pseudomonas fluorescens @10 $\mathrm{g} / \mathrm{lit}+10 \mathrm{~kg} / \mathrm{ha}$ at basal,45 and 90 DAS gave disease incidence $(7.63 \%)$ and yield (17.35t ha-1) both of treatments are statistically at par as regards in disease incidence and yield. Trichoderma act more effectively in controlling the disease through rhizosphere colonization, competition for nutrients etc.

\section{Introduction}

Ginger is one of the most important spice crop of India and draw the attention for its aroma and pungency. Among different diseases that attacking ginger, rhizome rot is the most vulnerable one causing serious damage to ginger and a major constraints for its production. Rhizome rot caused by Pythium sps. (3) is both soil and seed borne in nature(11). Soil borne plant pathogens play a major role in economic loss by creating threat to crop production. Use of chemical compounds thought to be a permanent and reliable solution of soil borne plant pathogens but at its due course of application it understood that use of pesticide is not safe to the environment as it contains harmful toxic chemicals which are hazardous to both soil and human beings.

To control a single targeted soil pathogen with chemical pesticide, over 100 species of non target organisms are adversely affected.(2). So present demand is to encourage the use of antagonistic 
microorganisms against soil borne plant pathogens to reduce the dose of chemicals. Such microorganisms are commonly referred to as biocontrol agents and their commercial formulations as biopesticides. Species of Trichoderma have proven its efficacy and reported by many workers towards the control of rhizome rot disease. $(4,12,14,8)$.

\section{Materials and Methods}

Experiment on "Iidentification of suitable biopesticides for rhizome rot management in ginger" has been conducted at HARS, Pottangi under Odisha University of Agriculture and Technology during 2018-19 and 2019-2020. Seven treatments were tested in the experiments, $\mathrm{T} 1=$ Rhizome treatment for 30 minutes with Trichoderma viride@10 g/lit.+ Pseudomonas fluorescens @ 10 g/lit; $\mathrm{T} 2=\mathrm{T} 1+$ application of $T$. viride and P.fluorescens @ $10 \mathrm{~kg} / \mathrm{ha}$ at basal, 45DAS and 90DAS; T3= Rhizome treatment for 30 minutes with Trichoderma viride @10g/lit. + application@10 kg/ha at basal, 45DAS and 90DAS; T4 = Rhizome treatment for 30 minutes with P. fluoroscens @ 10 g/lit.. + application@10 kg/ha at basal, 45DAS and 90DAS;T5= Rhizome treatment for 30 minutes with Trichoderma harzianum @ 10g/lit. + application @ $10 \mathrm{~kg} / \mathrm{ha}$ at basal, 45DAS and 90DAS;T6= Rhizome treatment for 30 minutes with Trichoderma harzianum @ 10 g/lit.+ Pseudomonas fluorescens@10 g/lit + application@10kg/ha at basal,45 and 90 DAS; T7 =Untreated control.

Bio agents fortified with FYM along with Neem cake + Azotobacter + Phosphorus Solublizing Bacteria + Potasium Mobilizing Bacteria for 21 days and then incorporated in soil just before sowing.

The experiments were laid out in RBD with three replications. Ginger variety Suprabha sown in the $3 \times 1 \mathrm{~m}^{2}$ plot size with row to row distance $30 \mathrm{~cm}$ and rhizome to rhizome distance was $25 \mathrm{~cm}$. Each plot was 10 rows and in each row four seed rhizomes of about 20 -25 gms were sown. Healthy rhizomes were treated with bioagents before sowing.

Rhizomes were dipped in solution of different bio agents for $30 \mathrm{mnts}$ and dried under shade before sowing in the field. Non treated seeds sown in control plots.

Same treatments which has been applied as basal again repeated at 45 and 90 days after sowing. Planting was done in the last week of April in both years with recommended dose of fertilizer, N:P:K @ 125:100:100.

Data on percent disease intensity, percent disease control and yield were recorded. Cumulative data of two years are presented. The weight of rhizome per plot was recorded and converted into per hectare yield.

\section{Results and Discussion}

All the treatments are significant to each other in percent disease intensity, percent disease control and rhizome yield as compared to control. Lowest percent disease intensity and highest percent disease control observed in treatment $\mathrm{T}_{6}$ followed by $\mathrm{T}_{2}$. All the treatments for management of rhizome rot in ginger were statistically significant with each other.

Percent Disease Intensity has been significantly reduced from 27.11 (untreated control) to 4.89 ( $\mathrm{T}_{6}$ Trichoderma harzianum @ 10 g/lit.+ Pseudomonas fluorescens @ 10 $\mathrm{g} / \mathrm{lit}+10 \mathrm{~kg} / \mathrm{ha}$ at basal,45 and 90 DAS.) followed by $\mathrm{T}_{2}$ (Rhizome treatment with Trichoderma viride @ 10 g/lit. and Pseudomonas fluorescens @ 10 g/lit + $10 \mathrm{~kg} / \mathrm{ha}$ at basal,45 and 90 DAS) with 7.63 Percent Disease Intensity. 
Table.1

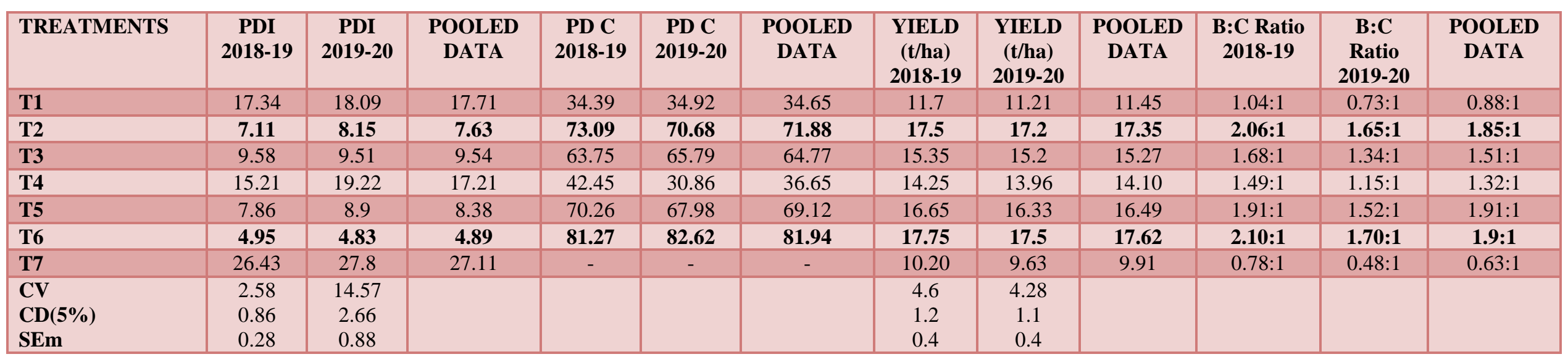


In conclusion the results indicated that $\mathrm{T}_{6}$ Trichoderma harzianum @ 10 g/lit.+ Pseudomonas fluorescens @ $10 \mathrm{~g} / \mathrm{lit}+$ $10 \mathrm{~kg} / \mathrm{ha}$ at basal,45 and 90 DAS gave minimum per cent disease incidence $(4.89 \%)$ and maximum yield (17.62t ha-1). The next best treatment was Rhizome treatment with Trichoderma viride @ 10 g/lit. and Pseudomonas fluorescens @ $10 \mathrm{~g} / \mathrm{lit}+$ $10 \mathrm{~kg} / \mathrm{ha}$ at basal,45 and 90 DAS) with 7.63 Percent Disease Intensity and 17.35 t ha-1 yield. Both treatments were found to be statistically at par with respect to reduction of disease intensity and increase in the yield. Abarazado, 1998 used Trichoderma spp. against rhizome rot of ginger successfully. Similar results were reported by Rajan et al., 2003 and Ghorpade et al., 1982 for the management of rhizome rot with T.harzianum.

Trichoderma strains grow rapidly when inoculated in the soil because they are naturally resistant to many toxic compounds including herbicides, fungicides and pesticides (6). For most filamentous fungi iron uptake is essential for viability(9). Trichoderma produce highly efficient siderophores that mobilize environmental iron and make available to it for its growth and at the same time retards the growth of pathogens by making iron unavailable to them(5).Root exudates excreted from root tip are the major source of nutrients for pathogens. Colonization of antagonist microorganisms in the rhizosphere of root tip reduce the secretion of root exudates thus unavailability of nutrients to the pathogens (7). Trichoderma has a superior capacity to mobilize and take up soil nutrients compared to other organisms. When nutrient availability decreases for pathogen through different mode of action like rhizosphere colonization, competition for nutrients etc then bio control agents act more effectively in controlling the disease. (2).

\section{References}

1. Abarazado, A. F., Lubao, J. A., Samoy, E. F. 1998.Biological control of ginger rhizome rot using Trichoderma spp. Philippine Journal of Crop Science, 23 (Supp. No.1). 91pp.

2. Alabouvette, C. and Y. Couteadier, 1992. Biological Control of Plant Diseases. Progress and Challenges for the Future. In:Biological Control of Plant Diseases, Tjamos, E.C.,G.C. Papavizas and R.J.Cook(Eds.), Plenum Press, New York,pp:415-426.

3. Bhardwaj, S. S., Gupta, P. K., Dohroo, N. P. and Shyam,K. R. 1988. Biological control of rhizome rot of ginger in storage. Indian Journal of Plant Pathology, 6: 56-58.

4. Chet, I., Harman, G. E. and Baker, R. 1981. Trichoderma hamatum its hyphal interaction with Rhizoctonia solani and Pythium spp. Microbial Biology, 7: 2938.

5. Chet,I. and J.Inbar 1994. Biological control of fungal pathogens. Applied Biochem. Biotechnol.,48:37-43.

6. Chet,I.,J.Inbar and Y.Hadar,1997.Fungal Antagonists and Mycoparasites.In: The Mycota. Environmental and Microbial Relationships, Wicklow, D.T. and B. Soderstrom (Eds.).Vol.4,Springer-Verlag, Berlin, Germany, pp:165-184.

7. Cook,R.J. and K.F.Baker,1983.The Nature and Practice of Biological Control of Plant Pathogens. $1^{\text {st }}$ Edn.,American Phytopathological Society, St.Paul, MN., USA., pp:539.

8. Dubey, S. C. 2003. Integrated management of web blight of urd bean/mung bean by bio-seed treatment. Indian Phytopathology, 56: 34-38.

9. Eisendle, M.,H. Oberegger, R.Buttinger, P.Illmer and H.Haas,2004.Biosynthesis and uptake of siderophores is controlled by the PacC-mediated ambient-Ph 
regulatory system in Aspergillus nidulans. Eukaryotic Cell,3:561-563.

10. Ghorpade, S. A. and Ajri, D. S. 1982. Effectiveness of oilseed cakes in control of rhizome rot. Journal of Maharashtra Agriculture University, 7: 272.

11. Kumar, R., Pandey, J. C. and Kumar, R. 1989. Chemical control of Rhizome rot of ginger by seed and soil treatment. Progressive Horticulture 21: 130-133.

12. Mukhopadhyay, A. N. 1994. Biocontrol of soil borne fungal plant pathogenscurrent status, future prospect, potential, and limitations. Indian Phytopathology, 47: 119-126.

13. Rajan, P. P., Gupta, S. R., Sharma, Y. R. and Jakson, G. V.H. 2003. Diseases of ginger and their control with Trichoderma harzianum. Indian Phytopathology, 55: 173-177.

14. Sankar, P. and Jayarajan, R. 1996. Seed treatment formulation of Trichoderma and Gliocladium for biological control of Macrophomina phaseolina in sesame. Indian Phytopathology, 49: 148-151.

\section{How to cite this article:}

Behera, S., P. Sial, G. Biswal and Pradhan, K. S. 2021. Role of Bio Pesticides towards Efficient Management of Rhizome Rot in Ginger. Int.J.Curr.Microbiol.App.Sci. 10(01): 941-945. doi: https://doi.org/10.20546/ijcmas.2021.1001.113 